\title{
Research on Energy Saving and Carbon Reduction of Cement Concrete in Factory with Precasting Structure
}

\author{
Jyhdong Lin ${ }^{1}$,Pinliang Liu ${ }^{2 *}$, a ${ }^{\text {, Minche } \mathrm{Ho}^{2, \mathrm{~b}} \text { and Minyen Huang }}{ }^{2, \mathrm{c}}$ \\ ${ }^{1}$ Professor of National Central University, City, Taoyuan County 32001 Taiwan (R.O.C.) \\ ${ }^{2}$ PH.D Studentof National Central University, City, Taoyuan County 32001 Taiwan (R.O.C.) \\ a*rt001398@gmail.com, bb1231520002000@hotmail.com, 'vi60113@gmail.com
}

Keywords: precast concrete plant, precast structure of life cycle, reduce carbon strategy

\begin{abstract}
The research is focused on the addition of energy conservation and carbon reduction into precasting concrete plant to improve the level of quality further. Application of the cost efficiency with the introduction of carbon calculator for the "carbon footprint" and lowering carbon emission strategies is further discussiond. During the life cycle of precasting structure, a good structure design incorporates not only the planning and design, but also its materials, equipment, and construction, which make up the important elements in preparing the final products in the precasting concrete plant.

By precasting structure of life cycle, good design in addition to the planning and design of building structures, precast concrete plant factory precasting products, materials, equipment and construction of a building structure unit of the finished product is very important element, and the energy conservation and carbon reduction import precasting concrete plant for further improve quality level, will cost when the subject research of the main shaft, through better understanding of concrete precasting factory, by the import carbon foot machine can statistics and energy cost savings to reduce carbon strategy;As the main direction of research papers.
\end{abstract}

\section{1 . Introduction}

Precast mechanization construction has less environmental impact due to unified construction methods which produces carbon energy saving effect; and contributesto economic investment plan. A minimum of 10 percent of the percentage is applied to the green materials, green or green energy construction method. The short-term objective of the National Energy Conservation Program is to reduce the total carbon footprint in the future 2030 to 2005 emission targets.

Carbon emissions if it does not reduce, the earth, approximately,in 30 years will suffer severe drought - Willey Interdisciplinary Reviews: Climate Change(2010). The latest study warning that unless greenhouse gas emissions reduced, most of the regions on Earth may within 30 years will face a very severe drought. Part of Asia, the US, Southern Europe, and most of the Africa, Latin America and the Middle East region in the coming decades will be affected by serious drought, and the area near Mediterranean region will face an "almost unprecedented" drought damages.

PrecastMethod (factory cast) first appeared in Europe, its strengths and weaknesses as follows:

Advantages:

1. Site need only base and the combination of work and finish the decoration, without the need for conservation and decrease duration.

2. Components Factory production, quality unified products.

3. The template can be used repeatedly without scaffold and support, only needs assemble workers, low cost savings.

Disadvantages:

1. Crane lifting and transport are more expensive and is restricted and the need to increase welders.

2. Assemble precision high, less changes of building outlook. 
The Precast Method in the precast factory from raw material, equipment, construction of carbon footprint section project inventory based on ISO 14064-1 standard calculated statistics pre-MOLTEN products in addition to its own advantages and disadvantages, and provides gas environment and energy savings resulting from the improved efficiency as statistics and identify more favorable to precast materials used in the factory and expand the use of the green sustainable construction and building materials for the purpose. Settings section Carbon Footprint General Objectives:

1. Energy savings objectives: future 8 years (since 2008) Energy efficiency every year more than 2 per cent of the energy density at 2015. More than 20 percent decline; by technology breakthroughs and complementary measures to 2030 declined more than $50 \%$.

2. Carbon reduction target: $\mathrm{CO}_{2}$ reduction, in 2030 the national carbon dioxide emissions back to 2005 emissions to 2030 national carbon dioxide emissions back to 2000 emissions.

November 3, 2011, the Executive Yuan publicizedthe "New Energy Policy" is to "ensure nuclear safety, lower dependency of nuclear plants, developing low carbon green environment, and steadily moving forward to non-nuclear power plants homes" as the overall energy development vision and the main driving force for policies of the energy-related objectives of the industry with energy efficient technology research and promotion applications. The current energy in promoting the development of science and technology is to study the development of technology-based industry, while at the same time advance participation and cooperation, technology licensing and other combination of domestic industry and the implementation of the research and development results to authorize the efficient industry production equipment and tools; through the final verification of nuclear energy, energy efficiency standards of control, such as the chapter energy policy instruments to promote efficient product manufacture and application.

\section{2 . LiteratureReview}

With regard to $\mathrm{CO}_{2}$ emissions-induced global warming is the most serious global environmental issues and for this reason is to talk about building $\mathrm{CO}_{2}$ emissions LCA assessment. The construction industry $\mathrm{CO}_{2}$ reduction issues, in addition to the general everyday use of energy, the rest of the section from building materials production of $\mathrm{CO}_{2}$ emissions. Building Materials Production of $\mathrm{CO}_{2}$ emissions and local energy structure and energy efficiency have close relations. For example, Norway 99 percent of electricity totally dependent on hydroelectric power, its clean units per ton oil equivalent of energy $\mathrm{CO}_{2}$ emissions (1.36t) only 52.7 percent of Taiwan and the thermal power generation accounted for 59 per cent of Japan, annual average energy emissions of $\mathrm{CO}_{2}$, about $0.533 \mathrm{~kg}$ is thermal powered accounted for approximately 74 per cent of Taiwan's 81\%. A domestic building materials of $\mathrm{CO}_{2}$ emissions in the energy statistics, regulations and statistics section has detailed the Ming and the results show that most of the metal building materials such as high processing, high $\mathrm{CO}_{2}$, high-energy emissions of building materials, in particular import of rough aluminum ingots of $\mathrm{CO}_{2}$ emissions are 8.6 times that of steel is a general cement 18.8 times, follow ISO14067 standards of carbon footprint analysis to prove that the factory is committed to environmental protection.

The building lifecycle LC, can generally be divided into (1) Building materials production, transport, construction works (2) Construction, (3) Day-to-day use, (4) Repair update, (5) Remove the Disposal, (6) Building materials recycling the six stages. The so-called building lifecycle of $\mathrm{CO}_{2}$ emissions is the sixth phase of the total $\mathrm{CO}_{2}$ emissions in this $\mathrm{LCCO}_{2}$ are called. To view $\mathrm{LCCO}_{2}$ assessment, day-today energy conservation in the housing $\mathrm{CO}_{2}$ reductions in response to occupy a position of absolute dominance. On the other hand, the same methods of assessing a 10-RC office building, also found in the construction process of building materials production, transport, construction $\mathrm{CO}_{2}$ emissions only accounted for 8.35 per cent of the $\mathrm{LCCO}_{2}$ that 40 years accrued daily consumption $\mathrm{CO}_{2}$ emissions is high on the 86.41 per cent. Day-to-day energy- $\mathrm{CO}_{2}$ emissions higher proportion of course, i.e. after the construction is completed daily consumption of $\mathrm{CO}_{2}$ emissions in the building lifecycle is large 
proportion of building energy management and maintenance of the building is the most important part of environmental protection.

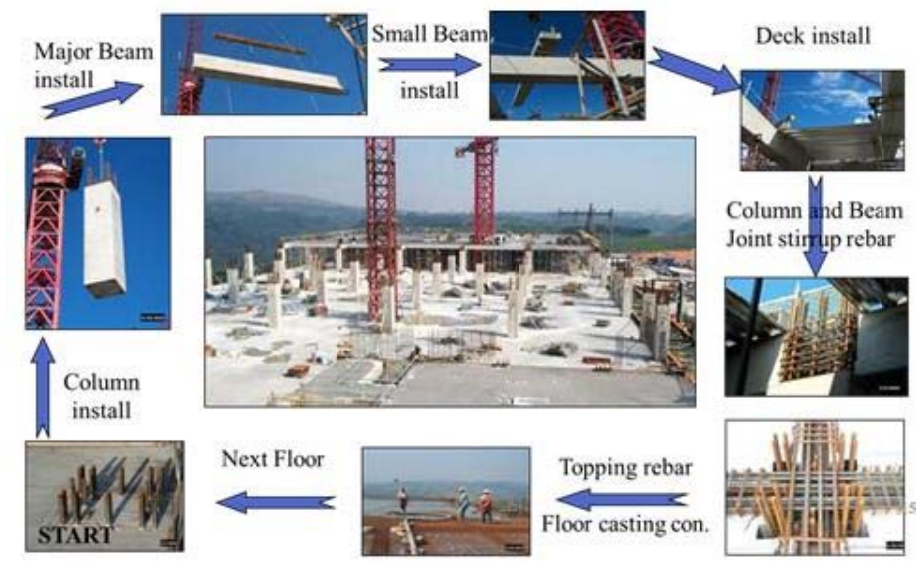

Fig. 1 Precast construre one floor to Install in site.(Source from Ruentex Co.,)

\section{Precast Plant Energy Saving and Carbon Reduction Discussion}

3.1 The Scope of the study and the examination configuration

Public Works schema specification Chapter 3, 03400 chapterprecast concrete, precast concrete components (products) of manufacturing, inspection, installation, and their materials and construction of the relevant provisions. 1. Cement concrete materials 2. Equipment Factory of production mold 3. Construction Products, transport and lifting as this section carbon footprint studies Discussion approach. The study mainly assess resource is a concrete and steel; two non-main assessment resources such as water, cement, sand with previous studies of manufacturing energy consumption data and its proportion to the product system add carbon emission calculation.Fllow the Road Map:
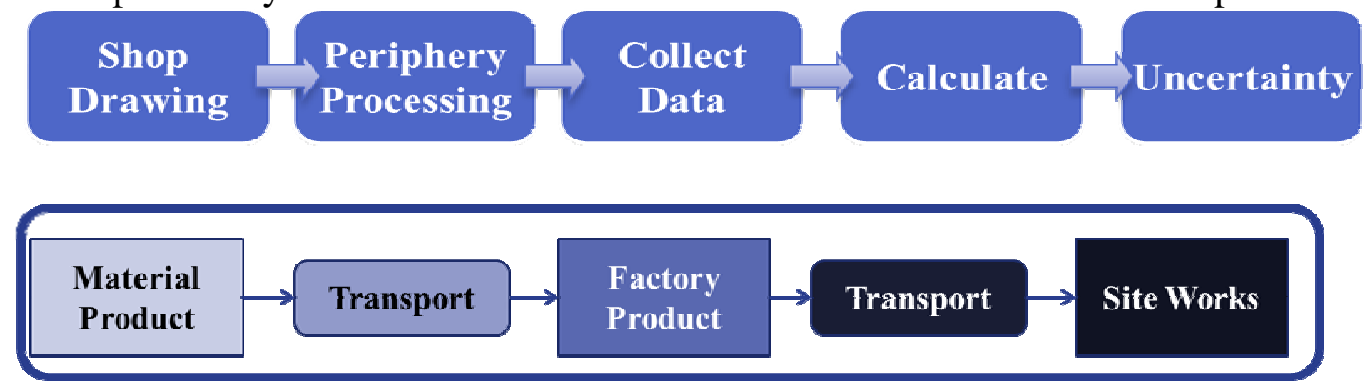

Areas of considerations and limit the carbon footprint calculation guidelines is provided in the product evaluation project is a comprehensive general clauses, based on product features with simple desktop life cycle assessment, and discounting is not suitable for evaluation of the project and the elements by itself to select suitable assessment project. The study is limited by the time and manpower to terrorism difficult to various factors of carbon emissions and therefore need to be incorporated into the evaluation will assess the scope of the project to reduce and limit, the following considerations and Limitations section description: its carbon emissions are defined as follows in Table 1:

The original value - Scrap Steel recycling of energy efficiency rate $=\times$ steel $\mathrm{CO}_{2}$ emission value (blast furnace steel GERM + rebar processing) (blast furnace steel GERM - electric arc furnaces steel GERM) 0.8. The development of precast construction steel cage up to section $43 \%$ average carbon footprint in recent years to heritage sites as success rate and therefore are not included in this research. 
3.2 Material precast concrete Discussion

Table 1 Amount of concrete cement and water-cement ratio (this research)

\begin{tabular}{|c|c|c|c|c|}
\hline & Cement $\left(\mathrm{kg} / \mathrm{m}^{3}\right)$ & $\mathbf{W} / \mathrm{C}+\mathbf{P}$ & Slump & $\begin{array}{c}\text { Reduction of } \\
\text { cement }\end{array}$ \\
\hline $\begin{array}{l}\text { Ordinary Portland } \\
\text { concrete (OPC) }\end{array}$ & 492.6 & 0.48 & small & - \\
\hline $\begin{array}{l}\text { High Strength concrete } \\
\text { (HSC) }\end{array}$ & $390 \sim 560$ & $0.3 \sim 0.4(\mathrm{Low})$ & small & $5 \sim 20 \%$ \\
\hline $\begin{array}{l}\text { High Preformance } \\
\text { concrete (HPC) }\end{array}$ & $\leqq 450$ & $0.2 \sim 0.45$ & big & 50\%(Up) \\
\hline $\begin{array}{c}\text { Roller Compacted } \\
\text { concrete (RCC) }\end{array}$ & 100 & 0.42 & small & 20\%(down) \\
\hline
\end{tabular}

1. Section Carbon Footprint Assessment System Creation: Confirm the boundary, if this is the clear definition of PCR(Product Category Rules) product range.

2. Each phase of the assessment and the methodology for the collection of the entire life cycle of all stages of the material usage, activity and emission factor data.

3. Now the visits of the advanced computing and carbon emissions data validation abroad; computing products carbon footprint.

4. Products carbon emissions; assessment of the carbon footprint analysis of accuracy.

\subsection{Device - Precast Factory}

With the ISO 9001 certification by the industrialization process to mold steel mold and the level of production and concrete indoor Gate Building and conservation to ensure quality precast components. Factory production and environmental stability and insulated from the effects of mechanical equipment manufacturing and operating standards of technical work needs small and human control process with the conservation of the environment, precision steel mold production.

Through standard modular design torque, and automates production processes to streamline management processes and reduce the overall duration of funds derived benefits so that total cost savings. Precast construction costs by traditional RC only limited cost competitive, precast technology can save $30 \%$ on deadlines and in early revenue and reduce interest expenses.

\subsection{Construction - precast concrete products PCR (Product Category Rules)}

Building durable design, the most effective way of providing durability (durability, serviceability maintainability), two responses. The first is the durability design" just simply increase structural strength is relatively easy to deal with countermeasures, and most effective design of the life cycle. According to expert estimates, structure should be structural strength by 20 percent, approximately can improve building life.

The second is the maintenance of the design of the building body and the device in the service line. The construction of the maintenance of the body design is simple, easy to clean, pollution of the design, as well as all-weather deep into the door and window design. The device line serviceability design of water, electricity, communication, fire gas pipes, devices such as the design of the "prove", as long as the existing planted many of RC Beams floor version of tubing in spite of, for Building Life Extension is a great help.

\subsection{Costs- the Difference of Traditional and Precast}

All precast structural members, pre-production factory production, site use of mechanized device only for group a pendant and immune to external eagle-painted and decorated synchronized to effectively decrease construction period; structure-wise at least saved 7 days per story; precast structure: 7 days; 
traditional structure: 14 days inspection report of a precast construction and decoration per story. No Fire-proof prime, no scaffoldsupport, and precast construction can work on decoration and equipment, electrical and mechanical works at the same time.

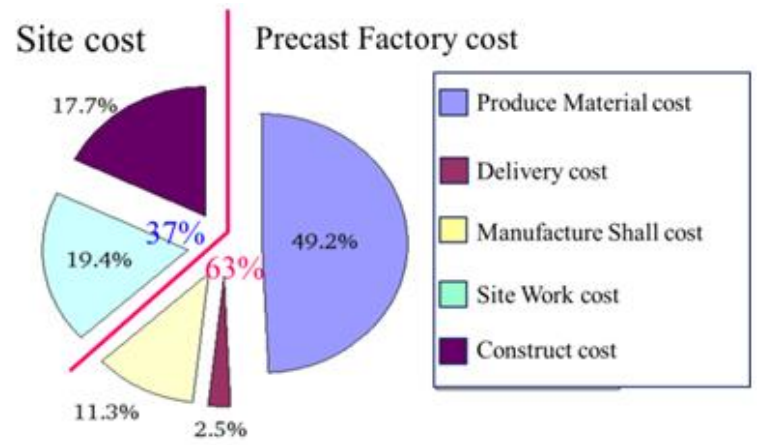

Fig. 2 Site and Precast Factory the difference cost

\subsection{Benefits - progress and quality Discussion}

The progress and quality of the differences are as follows:

1. MRS post structure size is small and floor height can be reduced, reduce overall structural steel, cement usage, comply with environmentally friendly and reduce transport costs.

2. Well maintained upkeep, or accompanied by pre-pressured precast structure will reduce cracks from dryness, and improve the quality of structure.

3. Factory production prevent pollution from site construction mix into concrete, will also avoid the structural holes and honey beehives situation in traditional construction sites.

4. Steel rebar is placed interior to reduce rust, also provides concrete with a strong hold.

5. Precast concrete, high-strength using traditional RC than the general use of concrete strength and material life and durability are better.

6. The uncleanness of the construction site from traditional methods of lumber cutting, discarded woods, rebar, residuals of concrete or leakage of concrete, large numbers of workers waste, resulting in difficult movement of walking, and etc., can all be improved by using precast method.

7. Precast requires a high threshold, currently only large manufacturers have precast capacity in Taiwan, and large construction companies can improve the fulfillment of the project contract.

8. Pre-mixed plants need to prepare a dedicated production line production with on-site manufacturing assembly continuous rotation, pre-mixed concrete factory can feed daily manufacturing, productivity and quality are also relatively easy to control.

\section{Precast Plant Prouction Energy Saving and Carbon Reduction Inventory Section Discussion}

\subsection{Study of Inventory Investigation Methods}

As a result of the location uncertainty of the exploitation of raw material production, the gathering information in similar locations is used and also compared Taiwan to the selected raw materials carbon emission factor as the basis of raw material production phase. The transportation distance during the raw material production phase is considered the distance between the raw materials site and the manufacturing plants, because their contractual and localization reasons.According to the calculation unit is divided into three stages:

1. Raw material stagecement, natural granules: production + transportation, ash: Handling + Transport

2. Manufacturing stage - the ratio: non-reference case study; mix of settings:device energy such as electricity,transport phase

3. Transportation stage - Product transportation, maintenance process built-in: transport equipment for the distance calculation 
This study uses the lab formula Xc\%\&Xw\% = Hearthstone with $(1)=$ Hearthstone, $(2)=$ recycled materials; a gray $=0$ (with pre-MOLTEN Products Quality Requirements:Not Use); Tin Port Pilot quantity $3^{\wedge} 3=27$ group arrangements with ratio adjustment try mix test informed the research needs of the ratio of the test and the test results of this study to Discussion.

\subsubsection{Cement}

Cement,cement is one of the concrete materials. The major raw materialsare limestone, clay, silicon sand, iron slag and gypsum. In the exploitation of coarse limestone, according to a certain proportion and clay, silicon sand and iron slag mixed, but internally there is no raw material extraction and transport-related research data and information obtained not easily, the exploitation of raw materials and Cement Transportation is not included in the scope of this study to assess follow-up concrete units, carbon emissions contains only the manufacturing process and product transportation. The transport phase are as follows: Table 2 as the research computing cement units average carbon, made after the organize this data to represent the cement unit and the subsequent carbon products Calculate carbon emissions, are this data.

Table 2 Cement unit process emissions

\begin{tabular}{|c|c|c|}
\hline Section & Product (ton) & Transport(ton) \\
\hline $\mathrm{Kg}-\mathrm{eCO}_{2} /$ unit & $\begin{array}{c}813 \\
813+5.98=819.2\end{array}$ & 5.98 \\
\hline
\end{tabular}

\subsubsection{Hearthstone}

The current domestic production from China Steel Company water-hardeninghearthstone is significant, and China Resources Companyis mainly converting the China Steel Company production of waterhardening hearthstone into water-hardening stone powder. The research is using the China Resources Company standard as listed in table 3 as the base unit for the water-hardening hearthstone powder calculation.

Table 3Slag unit process emissions

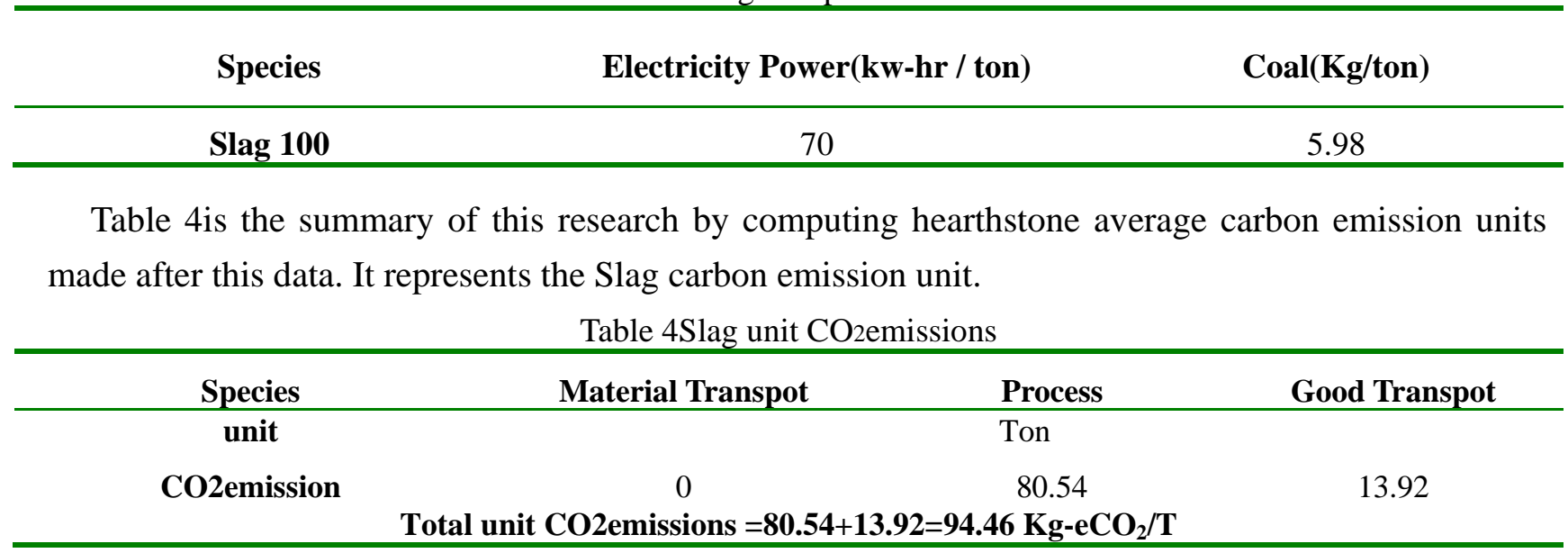

Summarize Table 2, Table 3 and Table 4 computing cement concrete material handling and transport energy-carbon emission unit into table 5 as follows:

Table 5Cement concrete unit Material Transpot and Processemissions

\begin{tabular}{cccc}
\hline Material & Product & Transport & unit CO2emissions \\
\hline Gravel (G) & 3.45 & 10.25 & $13.70\left(\mathrm{~kg}_{-} \mathrm{eCO}_{2} / \mathrm{m}^{3}\right)$ \\
Cement(C) & 940 & 5.98 & $945.98\left(\mathrm{~kg}_{-} \mathrm{eCO}_{2} / \mathrm{T}\right)$ \\
Slag(B) & 80.54 & 13.92 & $94.46\left(\mathrm{~kg}^{\mathrm{eeCO}} / \mathrm{T}\right)$ \\
\hline
\end{tabular}




\subsubsection{Structural Steel}

There are two major steel making methods,high temperature furnace steel making method; another is electrical furnace steel making method. The differences between is in the main materials used,the high temperature furnace steel making is using iron ore and electric furnaces steel making is from scrap metals. There exists a huge difference in terms of the energy used in both methodsas follows in Table 6:

Table 6 Structural Steel unit carbon emission tables source: This study to collate.

\begin{tabular}{lcccc}
\hline \multicolumn{1}{c}{ Material } & Unit & Product & Transport & Total \\
\hline Steel embryo (blast furnace) & $\mathrm{T}$ & 2119.65 & 5.62 & 2125.27 \\
Steel embryo (electric arc furnace) & $\mathrm{T}$ & 364.79 & 5.62 & 370.41 \\
Steel and iron pieces & $\mathrm{T}$ & 888.07 & 7.96 & 896.03 \\
Section steel & $\mathrm{T}$ & 904.26 & 7.96 & 912.22 \\
\hline
\end{tabular}

4.1.4 Structure material carbon emissions Summaryas follows in Table7:

Table7Coarse and fine aggregates material carbon emissions summary

\begin{tabular}{ccccc}
\hline Name & Unit & $\mathbf{e C O}_{2} \mathbf{g}$ & Year & Country \\
\hline Gravel & $\mathrm{M} 3$ & 3.11 & 2012 & Taiwan \\
Aggregate & $\mathrm{T}$ & 5.20 & 2006 & U.K. \\
Sand & $\mathrm{T}$ & 4.80 & 2006 & U.K. \\
Coarse aggregate & $\mathrm{T}$ & 5.10 & 2006 & Korea \\
Fine aggregate & $\mathrm{T}$ & 1.60 & 2006 & Korea \\
Gravel 1 & $\mathrm{T}$ & 1.03 & 2008 & Japan \\
Gravel 2 & $\mathrm{T}$ & 1.17 & 2008 & Japan \\
\hline
\end{tabular}

4.1.5 Cement carbon emissions Summaryas follows in Table 8:

Table 8 cement carbon emissions Summary

\begin{tabular}{cccc}
\hline Species & $\begin{array}{c}\text { Carbon Emissions } \\
(\mathbf{k g ~ e C O} / \mathbf{T})\end{array}$ & Source & Country \\
\hline & 503 & Report of the Ministry of the Environment & Japan \\
of Japan on GHG & British Cement ssociation & U.K. \\
& 930 (Type I) & - & India \\
Cement & 980 (Avg) & - & U.S. \\
& 930 & - & China \\
& 890 & Ministry of Economic Affairs & Taiwan \\
\hline
\end{tabular}


4.1.6 Cement Replacement carbon emissions Summaryas follows in Table 9:

Table 9 Replacecement in carbon emissions Summary

\begin{tabular}{ccccc}
\hline Material & $\begin{array}{c}\text { limestone } \\
(\mathbf{k g})\end{array}$ & Coal burning (kg) & Electricity (degree) & $\begin{array}{c}\text { Carbon Emissions } \\
\left.\mathbf{( k g - e C O}_{2} / \mathbf{T}\right)\end{array}$ \\
\hline Slag & 0 & 14 & 70 & 52.2 \\
Cement & 1200 & 110 & 110 & 940 \\
difference & -1200 & -96 & -40 & -887.8 \\
\hline
\end{tabular}

Note: Factory use sub-meter single power computing and Taiwan Power Company with the table and power factor electricity price differences as the basis of error correction reference.as follows in Table10, Table 11and Table 12:

Table 10Equipment Mixed concrete plant energy consumption

\begin{tabular}{ccccccc}
\hline $\mathbf{k g f} / \mathbf{c m} 2$ & $\mathbf{2 1 0}$ & $\mathbf{2 4 5}$ & $\mathbf{2 8 0}$ & $\mathbf{2 8 0}(\mathbf{W})$ & $\mathbf{3 5 0}$ & $\mathbf{3 5 0 ( S C C )}$ \\
\hline Electricity (degree) & 1.6493 & 1.7409 & 1.6135 & 1.5657 & 1.6092 & 1.1433 \\
\hline
\end{tabular}

Table 11Comparison of Two Kinds of Premixed Truck Transportation

\begin{tabular}{cccc}
\hline & Car species & Business & For Personal Use \\
\cline { 2 - 5 } & Weight(Ton) & $1,821,430$ & $85,675,803$ \\
& Yenton kilometers (Ton-Kms) & $38,107,313$ & $1,109,768,261$ \\
& Freight rate per metric ton & 13.2434 & - \\
& (Average Freightper Ton-Km) & 13.12 & 13.12 \\
& Average distance (Km) & & 13.12 \\
& Carbon emissions $\left(\mathrm{kg} \mathrm{CO}_{2}-\mathrm{e} / \mathrm{m}^{3}\right)$ & & 2.28 \\
\hline
\end{tabular}

Table 12Comparison of Transport Stages at Different Stations

$$
\begin{aligned}
& \text { Average distance (km) } \\
& \text { Car species }\left(\mathrm{m}^{3}\right) \\
& \text { Fuel consumption }(\mathbf{L} / \mathbf{k m}) \\
& \text { Diesel Coefficient }\left(\mathrm{kg}-\mathrm{eCO}_{2} / \mathrm{L}\right) \\
& \text { Carbon emission }\left(\mathbf{k g - e C O} \mathrm{C}_{2} / \mathrm{m}^{3}\right) \\
& \text { Yield }\left(\mathrm{m}^{3}\right) \\
& \text { Weighted average }\left(\mathrm{kg}-\mathrm{eCO}_{2} / \mathrm{m}^{3}\right)
\end{aligned}
$$

\begin{tabular}{cccc} 
Plant A & Plant B & Plant C & Plant D \\
\hline $60-80$ & $20-40$ & 15 & $10-20$ \\
6 & 6 & 8 & 8 \\
0.4 & 0.4 & 0.4 & 0.4 \\
2.61 & 2.61 & 2.61 & 2.61 \\
$10.44-13.92$ & $3.48-6.96$ & $13.1-2.61$ & $1.31-2.61$ \\
240000 & 100000 & 200000 & 413700 \\
\multicolumn{2}{c}{$3.83-5.91$} & \\
\hline
\end{tabular}

4.2 Carbon Reduction Benefits Analysis of Products

Methodology: Calculation of the product life cycle all occurred in raw materials, energy and waste phase of activities multiplied by its corresponding emission factors and is added to the total carbon footprint of calculation. Calculated as follows: activities of carbon footprint $=$ Activity Data Quality/volume $) \times / \mathrm{kwh} / \mathrm{km}$ emission factors $\left(\mathrm{CO}_{2} \mathrm{E}\right.$ per unit) due to the PAS 2050 Considerations Product carbon storage in effect, the sum of the emissions after deducting the amount of carbon storage, which is a product lifecycle greenhouse gas emissions. In addition, PAS 2050 and requires the calculation should note the quality balance (mass balance, i.e. inflow into the quality process should be equal to the outflow of uneven quality, if the quality is a part of the process flow is not computing (usually a waste) whereby view is complete computing a process of carbon emissions. 
4.2.1 Portland cement concrete proposals to reduce carbon benefits analysis

Cement concrete is to cement or cement the right amount is mixed with the materials, water and coarse and fine aggregates, or add additional agents or other materials to press an appropriate proportion with a mix of mixed property to the Gate Building in a time process and freezing of the artificial stone. But it is also present concrete construction energy consumption and carbon dioxide emissions in industrial and is thus able to control the use of concrete materials to achieve the energy is the best path to a carbon footprint.As concrete proposals to achieve the savings less carbon reduction in the emissions of carbon is usually the most direct way to cement usage by reducing the hand, the most frequently used substitutes is water-heaters stone powder, the research that is calculated in the direction toward the reduction of their carbon benefits.

\subsubsection{Self Compacting Concrete carbon reduction benefits analysis}

The fill Self-Compacting- Concrete (SCC) means the internal process does not require the imposition of vibration, completely smashed by its own gravity filler to steel and steel and steel and template of the corners of the Special concrete. Because their mobility and fill performance filler steel clearance and templates in every corner of the world to minimize human rate for an improper and save manpower and improve traditional steel and concrete pouring into the secret because it is not easy to persuade or causing the cellular" phenomenon. So the refill concrete effectively to overcome traditional concrete construction in real bad, missing the ills, improves the quality of concrete filling achieve better performance and material homogeneity.

4.3 Carbon footprint calculation and life cycle assessment

According to the Environmental Protection Department, by carbon footprint calculation guidelines, the study of the spirit of integration in the past for product carbon footprint calculation or life cycle assessment studies related to the assessment of the law as indicated in table $11 \& 12$ will be used as the basis for the follow-up research literatureas follows in Table 13:

Table13 Construction structure product need with carbon reduction benefits unit

\begin{tabular}{clc}
\hline item & \multicolumn{1}{c}{ Product } & Formula \\
\hline $\mathbf{1}$ & Protland Concrete & $724.81 \times \mathrm{B}+805.35 \times \mathrm{F} \mathrm{kg}-\mathrm{eCO}_{2} / \mathrm{m}^{3}$ \\
$\mathbf{2}$ & Self Compacted Concrete & $724.81 \times \mathrm{B}+805.35 \times \mathrm{F}+\mathrm{Po}-\mathrm{SPo} \mathrm{kg}^{-\mathrm{eCO}_{2} / \mathrm{m}^{3}}$ \\
$\mathbf{3}$ & Rebar and Item(St) & $247.312 \mathrm{St} \mathrm{kg-eCO} / \mathrm{T}$ \\
$\mathbf{4}$ & Steel(Se) & $263.536 \mathrm{Se} \mathrm{kg}-\mathrm{eCO}_{2} / \mathrm{T}$ \\
$\mathbf{5}$ & Stainless steel (Ss) & $315.936 \mathrm{Ss} \mathrm{kg-eCO} / \mathrm{T}$ \\
$\mathbf{6}$ & Hot rolled coil (Hr) & $281.992 \mathrm{Hr} \mathrm{kg-eCO} / \mathrm{T}$ \\
$\mathbf{7}$ & Cold rolled coil (Cr) & $253.424 \mathrm{Cr} \mathrm{kg}-\mathrm{eCO}_{2} / \mathrm{T}$ \\
$\mathbf{8}$ & Stainless steel pipe (Ps) & $317.488 \mathrm{Ps} \mathrm{kg-eCO} / \mathrm{T}$ \\
$\mathbf{9}$ & Galvanized steel pipe (Pg) & $283.456 \mathrm{Pg} \mathrm{kg}-\mathrm{eCO}_{2} / \mathrm{T}$ \\
$\mathbf{1 0}$ & Cold-rolled steel pipe (Pc) & $250.152{\mathrm{Pc} \mathrm{kg}-\mathrm{eCO}_{2} / \mathrm{T}}$ \\
\hline
\end{tabular}

\section{Foreign and Domestic precast project inventory of carbon benefits Discussion}

5.1 Foreign precast concrete energy saving _ carbon emissions

The European technology cooperation in the precast concrete manufacturers an 2 ELEMATIC, Finland and Germany PCE by the European use of cement material used in the precast Taiwan also consider more than the ambient temperature difference resulting from], precast plant has been designed central air conditioning full operating environment construction to ensure the quality of precast concrete; in this study does not include this itemas follows in Table 14:. 
Table 14 Difference Subcontacts Products Carbon Emissions Calculations

\begin{tabular}{|c|c|c|c|c|c|}
\hline \multirow[b]{3}{*}{ Subcontact A } & \multirow[t]{2}{*}{ Electricity (degree) } & \multirow[t]{2}{*}{ Fuel consumption (L) } & \multirow{2}{*}{$\begin{array}{l}\text { Yield } \\
\text { (T) }\end{array}$} & $\begin{array}{c}\text { Carbon } \\
\text { Emissions }\end{array}$ & $\begin{array}{c}\text { Weighted } \\
\text { Average }\end{array}$ \\
\hline & & & & kg-eCO ${ }_{2} / \mathrm{T}$ & kg-eCO $2 / \mathrm{T}$ \\
\hline & 9600 & 120 & 4000 & 1.56 & \\
\hline Subcontact B & - & 1000 & 960 & 2.68 & \\
\hline Subcontact C & 8200 & 350 & 3500 & 1.69 & 1.74 \\
\hline $\begin{array}{c}\text { Foreign data } \\
\text { trial }\end{array}$ & $\begin{array}{r}(0.132+0.039) / 0.0 \\
* 2.61[\text { Diesel }\end{array}$ & $\begin{array}{l}\text { thinkness] /2.35[Mixprop } \\
\text { arbon emission coefficien }\end{array}$ & ion] & 6.33 & \\
\hline
\end{tabular}

5.1.1 OPC \& SC concrete products calculationas follows in Table 15:

Table 15 OPC \& SCC Concrete ProductsCarbon Emissions Calculations

\begin{tabular}{|c|c|c|c|c|c|c|c|}
\hline OPC & Cement & Water & Chemical & Slag & Aggregate & Sand & Total \\
\hline Unit & & & & $\left(\mathrm{kg} \mathrm{CO} / \mathrm{m}^{3}\right)$ & & & \\
\hline $280 \mathrm{kgf} / \mathrm{cm}^{2}$ & 307.35 & 11.76 & 0.24 & - & 42.58 & 22.80 & 384.73 \\
\hline $350 \mathrm{kgf} / \mathrm{cm}^{2}$ & 347.59 & 11.69 & 0.29 & - & 42.58 & 20.91 & 423.07 \\
\hline SCC & Cement & Water & Camical & Slag & Aggregate & Sand & Total \\
\hline Unit & & & & $\left(\mathrm{kg} \mathrm{CO} \mathrm{CO}_{2} / \mathrm{m}^{3}\right)$ & & & \\
\hline $280 \mathrm{kgf} / \mathrm{cm}^{2}$ & 226.85 & 10.08 & 0.34 & 11.17 & 35.86 & 27.44 & 311.73 \\
\hline $350 \mathrm{kgf} / \mathrm{cm}^{2}$ & 256.12 & 11.45 & 0.39 & 13.62 & 36.45 & 25.63 & 343.66 \\
\hline
\end{tabular}

The data source is from the Environmental Protection Department 1. Refer to the Environmental Protection Department's new http://cfp.epa.gov.tw/carbon/defaultpage.aspx factor

2. weight unit of data on the basis of actual mix 3. Product Carbon Footprint process in accordance with item 4 . Uncertainty added to the calculation.

\subsubsection{Progress Comparison}

Technology, precast structure with at least shortened 7 days per story; G traditional structure, 7 days one story, 14 days inspection, and precast construction and decoration to every floor from a batch of reply, non-cultivation-base thin toner light, from ground frame decoration, motor and device can synchronize construction works, precast structure to 45 days after completion may apply for the use licenseas follows in Fig .3 and Fig. 4 and OPC compare SCC reducecarbon emissions calculations as follows Table 16:

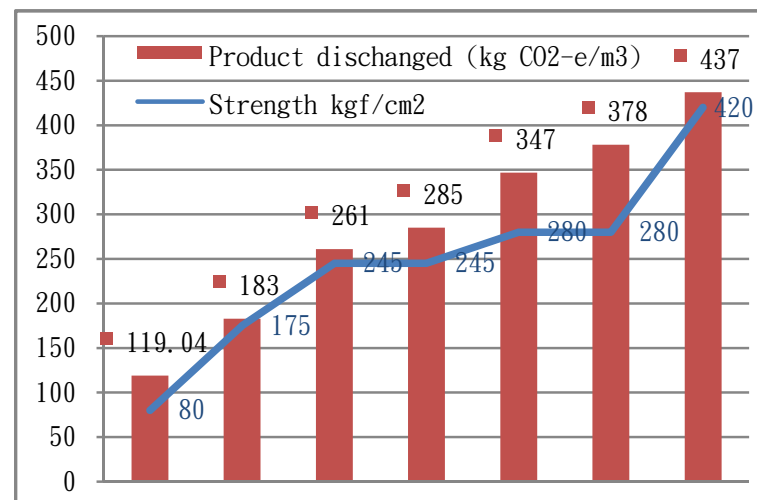

Fig. 3 Concrete Strangth and Carbon Emissions

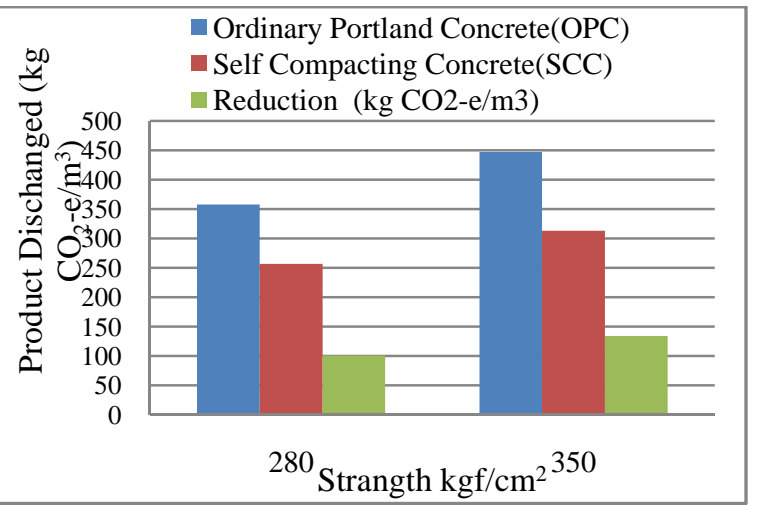

Fig. 4 OPC and SCC Produce Carbon Emissions 
Table16. OPC \& SCC Concrete Reduce Carbon Emissions Calculations(350kgf/cm²)

\begin{tabular}{lcc}
\hline & OPC & SCC \\
\hline Material $\left(\mathrm{kg} \mathrm{CO}_{2} / \mathbf{m}^{\mathbf{3}}\right)$ & 423.07 & 343.66 \\
Production $\left(\mathrm{kg} \mathrm{CO}_{2} / \mathbf{m}^{\mathbf{3}}\right)$ & 1.747 & 1.144 \\
Transport $\left(\mathrm{kg} \mathrm{CO}_{2} / \mathbf{m}^{\mathbf{3}}\right)$ & 4.87 & 4.87 \\
Total $\left(\mathbf{k g ~ C O} \mathbf{~ m}^{\mathbf{3}}\right)$ & 429.68 & 349.67 \\
Reduce $\left(\mathrm{kg} \mathrm{CO} \mathbf{C O}_{2}-\mathbf{e} / \mathbf{m}^{\mathbf{3}}\right)$ & & 80.01 \\
\hline
\end{tabular}

\subsection{Precast factory Lifecycle}

Japan had to office buildings 50 years lifecycle for economic assessment and found that the initial planning, design, construction cost is only 26 percent of trading, repair, update, accounted for 27\%, 50 years of hydroelectric energy expenditure accounted for $21 \%$, taxes, interest and insurance general management costs accounted for 26 percent. I.e. the LCA investment from the economic perspective, office building of the initial cost accounted for only about a quarter of the cost of the operation up to three times that of the initial cost. Thus the green building designers and must never be ignored after construction is completed environmental impact assessment, only to the LCA assessment is modern green building features. Lca is modern Value Engineering The basic doctrine".

5.4 E-management and information platform control construction management

To achieve the project can be completed on schedule (time), cost budget (budget) to complete the project scope (Scope) with quality, allows owners satisfied with the ultimate goal of the project management from concept to actual investment project level of control for project teams and a more effective functioning of the best environment and functionality.

Fig. 5 Ruentex Cement Factory(From Google) Fig.6 Hearing Impaired Olympics (From Runhong Co.,)
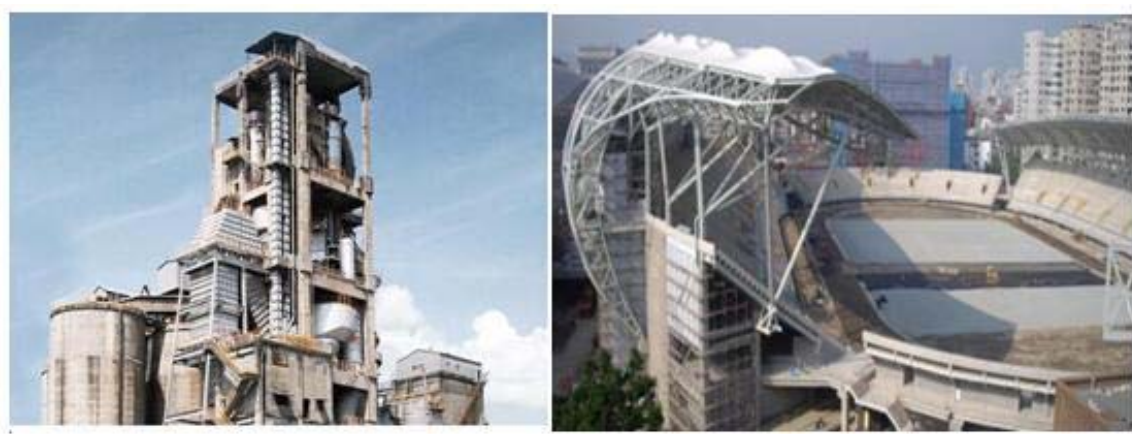

5.4.1Manufacturers supply energy saving and carbon reduction benefitsas follows in Table17

Table17Benefit of Precast Concrete

\begin{tabular}{cccc}
\hline Item & Reduce Carbon Emissions & $\begin{array}{c}\text { Cost Down } \\
\text { (NTD) }\end{array}$ & $\begin{array}{c}\text { Note } \\
\text { Data From }\end{array}$ \\
\hline Cement Factory(Supplier) & 23,311 ton & $35,020,000$ & Economic Daily \\
Hearing Impaired Olympics & $51,485 \mathrm{~m} 2$ & $2,316,825$ & Runhong Net \\
Neutralize Site Project & 365.123 ton & 683,280 & This research \\
\multicolumn{1}{c}{ Total=NTD } & & $38,020,105$ & \\
\hline
\end{tabular}




\section{Conclusions and recommendations}

\subsection{Conclusion}

The study collected all raw material carbon emission factors from all over the world within a range, a reasonable inference is that due to different carbon emission factors used throughout countries. Cement concrete products carbon emissions maximum impact factor is a product of cement material, if the proportion of the same design under the intensity of the nature of their works, if you can increase the volume of cement material is replaced with the highest minus carbon benefits.

Concrete itself in the production must be on to use more attachment, but differences can cause the resin itself less carbon effects and therefore to a larger overall product carbon emissions, $280 \mathrm{kgf} / \mathrm{cm}^{2}$ concrete per ton of carbon emissions reduced $384.73 \mathrm{~kg} \mathrm{Co}_{2}-\mathrm{e} / \mathrm{m}^{3}$ to $311.73 \mathrm{kgco}_{2} \mathrm{e} / \mathrm{m}^{3}$ about 72.99 $\mathrm{kgCO}_{2} \mathrm{e} / \mathrm{m}^{3}$ of approximately $18.97 \%$.

\subsection{Recommendations}

Precast plant derived energy research issues related carbon reduction recommendations are as follows:

1. Production Equipment Automation generate energy carbon reduction effects of system study and channel research, such as layout automatically Steel Bending Machine processing of human machine infeed law ring savings effect reflected in reduced carbon computing.

2. Application ISO 14000 environmental management system, establish a complete set of energy saving and carbon reduction building management and audit system.

\section{References}

[1]. Yuanhuihao ${ }^{『}$ Application of Construction Precasting Method, Ministry of Interior Building Research, Chapter 3, (1995) p25 69。 。

[2]. Jyhdong lin $『$ The 9th Public Works Quality Management Seminar 』, National Central University , (2004) p25 53。

[3]. Ruentexi Group ${ }^{『}$ Runhong Precision Engineering Company Limited - style open specification Taipei ，2010 • Ruentexi Group Global Service Website http://www.ruentex.com.tw/

[4]. Jinhuai yangeditor , P Proceedings of the Symposium on Precasting Method , Taiwan Construction Research Institute，2004。

[5]. Executive Yuan Environmental Protection Department Taiwan Product Carbon Footprint Information Network, Internet time : 2015/03

[6]. Ministry of Economic Affairs Energy Bureau Energy Industry Greenhouse Gas Reduction Information Network, Internet time : 2015/03

[7]. Ministry of Economic Affairs Industry Bureau Manufacturing Product Carbon Footprint Information Zone ,http://idbcfp.nccp.org.tw/index.aspx, Internet time : 2015/03

[8]. Eoshengchang, Assessment of Carbon Dioxide Reduction in Building Life Cycle , National Cheng Kung University Building Research Institute , (2002 )p25 65 。

[9]. China United Resources Co., Ltd., "China United Resources Co., Ltd. Annual Report 98" , 05 / 2010.

[10].British Standards, "Guide to PAS 2050 How to assess the carbon footprint of goods and services”,2008. 
[11]. British Standards, "Specification for the assessment of the life cycle green house gas emissions of goods and services”,2008.

[12].Low, S.P. and Choong, J.C. “Just-in-time management of precast concrete component,” Journal of Construction Engineering and Management, ASCE, 127 (3), (2001)p 494-501. 